\title{
Peran Inspektorat Dalam Pelaksanaan Sistem Pengendalian Intern Pemerintah Pada Pemerintah Daerah Kabupaten Kepulauan Talaud
}

\author{
ANGEL WULANDARI MANIALUP ${ }^{1}$, GRACE B. NANGOI ${ }^{2}$, JENNY MORASA ${ }^{3}$ \\ ${ }^{1,2,3}$ Program Magister Akutansi, Fakultas Ekonomi dan Bisnis Universitas Sam Ratulangi \\ email : enji.liong@gmail.com ${ }^{1}$,gracebn@yahoo.com ${ }^{2}$, jennymorasa@ hotmail.com
}

\begin{abstract}
Government Internal Control system is a system of internal control implemented whole in the central government and local government. If the Government Regulation Number 60 year 2008 is performed effectively, it will support to minimize the occurrence of oversights. The purposes of this research are : (1) To find out the roles of Inspectorate in the implementations of GICS in Talaud Islands Regency; (2) To analyze the challenges and difficulties that affect the Inspectorate roles in the implementation of Government Internal Control System (GICS) in Talaud Islands Regency; (3) To analyze the Inspectorate efforts to improve the implementation of GICS in Talaud Islands Regency. This study is a qualitative exploratory research. Data were collected through interviews, observation, and documentation study. Data consists of primary and secondary data. The interviews were transcribed, analyzed, coded and categorized into themes. Data was analysed by content analysis. The research findings show that Inspectorate holds important roles in GICS Implementation in Talaud Regency, such as leadership, internal control, consultancy and quality assurance. Difficulties influence the Inspectorate roles in GICS implementation in Talaud Regency are: the absence of both regent regulation and the organization of GICS task force, inadequate human resources understanding of GICS and lack of membership, insufficient budget for control activities, inexistence of joint commitment in implementing GICS as well as risk assessment and non-optimal risk planning due to time limitations. Efforts conducted by Inspectorate in order to improve the Implementation of GICS in Talaud Regency are to suggest the frame of regent regulation and GICS task unit, improve the quality of resources through education, trainings, technical seminar or office training, counselling, coordinate the education improvement with many institutions such as BPKP, add extra budgeting for control activities, establish joint commitment in GICS implementation, carry out risk assessment and risk planning optimally and develop effective communication with SKDP as well as BPKP.
\end{abstract}

Keywords: The role of Inspectorate, GICS implementation, difficulties, efforts

\begin{abstract}
Abstrak. Sistem Pengendalian Intern Pemerintah adalah Sistem Pengendalian Intern yang diselenggarakan secara menyeluruh di lingkungan pemerintah pusat dan pemerintah daerah. Peraturan Pemerintah No. 60 tahun 2008 tentang SPIP jika dilakukan dengan efektif akan sangat membantu untuk meminimalisir risiko terjadinya kesalahan. Penelitian ini bertujuan untuk : (1) Mengetahui bagaimana peran Inspektorat dalam pelaksanaan Sistem Pengendalian Intern Pemerintah (SPIP) di Kabupaten Kepulauan Talaud; (2) Menganalisis kendalakendala yang mempengaruhi peran Inspektorat dalam pelaksanaan SPIP di Kabupaten Kepulauan Talaud; (3) Menganalisis upaya-upaya yang dilakukan Inspektorat untuk meningkatkan pelaksanaan SPIP di Kabupaten Kepulauan Talaud. Penelitian ini menggunakan jenis penelitian kualitatif dengan pendekatan eksploratori. Pengumpulan data dilakukan melalui wawancara, observasi dan studi dokumentasi. Terdiri dari data primer dan data sekunder. Hasil wawancara ditranskrip menjadi transkrip data, kemudian dianalisis, diberi kode, dan dikategorikan ke dalam tema. Analisis data menggunakan analisis isi. Hasil penelitian menunjukkan bahwa Peran Inspektorat dalam pelaksanaan SPIP di Kabupaten Kepulauan Talaud yaitu dalam hal kepemimpinan, pengawasan intern, konsultan dan penjamin mutu. Kendala-kendala yang mempengaruhi peran Inspektorat dalam pelaksanaan SPIP di Kabupaten Kepulauan Talaud yaitu belum adanya Peraturan Bupati dan belum membentuk Satuan Tugas SPIP, pemahaman SDM akan SPIP masih kurang dan jumlah personil belum memadai, anggar kegiatan pengawasan kurang memadai, belum ada komitmen bersama dalam melaksankan SPIP serta penilaian risiko dan pemetaan risiko belum optimal karena keterbatasan waktu. Upaya-upaya yang dilakukan Inspektorat untuk meningkatkan pelaksanaan SPIP di Kabupaten Kepulauan Talaud adalah dengan mengusulkan penyusunan Peraturan Bupati dan pembentukan Satuan Tugas SPIP, meningkatkan kualitas sumber daya, melalui jenjang pendidikan, diklat-diklat, pelatihan kantor sendiri, pembinaan, melakukan koordinasi meningkatkan pendidikan dengan lembaga-lembaga seperti BPKP, menambah anggaran kegiatan pengawasan, membangun komitmen bersama dalam melaksanakan SPIP, melakukan penilaian risiko dan pemetaan risiko secara optimal dan membangun komunikasi yang efektif dengan SKPD maupun BPKP.
\end{abstract}

Kata kunci: Peran Inspektorat, pelaksanaan SPIP, kendala, upaya 


\section{Pendahuluan}

Sistem Pengendalian Intern sangatlah diperlukan dalam menjalankan roda pemerintahan. Sistem ini dapat berjalan jika seluruh unsur yang terlibat dalam pemerintahan memiliki pengetahuan, kemampuan dan kemauan untuk menjalankan secara bersamaan dan berkelanjutan. Agar penyelenggaraan pemerintahan berjalan dengan baik, Sistem Pengendalian Intern Pemerintah seharusnya dilaksanakan secara bersamaan dan berkelanjutan, mulai dari perencanaan, pelaksanaan, pengawasan, sampai dengan pertanggung jawaban berjalan dengan tertib, terkendali serta efektif dan efisien. Berdasarkan amanat peraturan perundang-undangan Sistem Pengendalian Intern Pemerintah berfungsi sebagai pedoman penyelenggaraan dan tolok ukur pengujian efektivitas penyelenggaraan SPIP, yaitu Peraturan Pemerintah Nomor 60 Tahun 2008 tentang Sistem Pengendalian Intern Pemerintah. Sebagaimana disebutkan dalam Peraturan Pemerintah Republik Indonesia Nomor 60 Tahun 2008 tentang Sistem Pengendalian Intern Pemerintah, didalamnya menyatakan bahwa Inspektorat kabupaten/kota adalah Aparat Pengawasan Intern Pemerintah yang bertanggung jawab langsung kepada Bupati/Walikota.

Sangat diharapkan proses yang integral pada tindakan dan kegiatan benar-benar dapat dilakukan secara terus menerus oleh pimpinan dan pegawai agar dapat memberikan keyakinan memadai atas tercapainya tujuan pemerintah melalui kegiatan yang efektif dan efisien, keandalan pelaporan keuangan, pengamanan aset daerah serta ketaatan terhadap peraturan perundang-undangan sebagaimana maksud mendasar dari Sistem Pengendalian Intern itu sendiri. SKPD memiliki peran masing-masing dalam membangun SPIP diunit kerjanya dan Inspektoratlah yang akan mengawal dan menilai efektivitas pelaksanaan SPIP tersebut. Untuk itu dibutuhkan suatu sistem yang dapat memberi keyakinan memadai bahwa penyelenggaraan pemerintah dapat mencapai tujuannya secara efektif dan efisien, melaporkan pengelolaan keuangan daerah secara andal, mengamankan aset daerah dan mendorong ketaatan terhadap peraturan perundang-undangan. Dalam penerapan Sistem Pengendalian Intern Pemerintah Daerah dibutuhkan komitmen mulai dari pimpinan dan seluruh pegawai agar bisa mencapai tujuan bersama. Dan untuk menghasilkan laporan pertanggungjawaban yang baik diperlukan Sistem Pengendalian Intern Pemerintah yang handal, transparan, akuntabel dan sesuai ketentuan. Pemerintah Daerah Kabupaten Talaud berupaya untuk bisa menjalankan Sistem Pengendalian Intern dengan sebaik mungkin agar bisa mencapai tujuan bersama.

Selain itu Insperktorat berperan untuk memastikan penyelenggaraan SPIP dipemerintah daerah sudah bejalan dengan baik sesuai dengan ketentuan/pedoman serta melakukan pemantauan secara berkala, karena penyelenggaraan Sistem Pengendalian Intern Pemerintah di SKPD merupakan motor penggerak organisasi. APIP dalam hal ini Inspektorat Kabupaten Kepulauan Talaud merupakan garis pertahanan terakhir, tanpa adanya pengendalian Internal maka semakin besar peluang terjadinya permasalahan. Artinya Kabupaten Kepulauan Talaud harus berupaya lebih keras lagi untuk meningkat dari level 2 (berkembang) ke level 3 (terdefinisi) Maturitas Sistem Pengendalian Intern Pemerintah. Jika hal tersebut bisa terlaksana dengan baik maka program/kegiatan bisa berjalan efektif dan efisien dengan laporan keuangan yang handal serta peluang untuk maju menjadi lebih baik dengan Opini Wajar Tanpa Pengecualian sudah ada didepan mata. Hal ini menegaskan besarnya Peran Inspektorat Kabupaten Kepulauan Talaud dalam terwujudnya Sistem Pengendalian Intern Pemerintah yang baik.

Dalam Laporan Hasil Pemeriksaan (LHP) BPK-RI tahun 2016 untuk buku II yaitu mengenai SPI, terdapat temuan SPI menunjukkan lemahnya pengelolaan pada Sistem Pengendalian Intern. Pada prakteknya pemerintah Kabupaten Kepulauan Talaud sering tidak konsisten dalam menjalankan SPIP. Permasalahan di Kabupaten Kepulauan Talaud secara umum terlihat pada lemahnya pengendalian intern kegiatan SKPD dan pemerintah kabupaten yang seharusnya dilaksanakan tapi belum diterapkan dengan optimal. Adanya temuan berulang serta penatausahaan dan pengelolaan Aset tetap belum memadai, belum dibuat Satuan Tugas SPIP serta berbagai kelemahan Sistem Pengendalian Intern lainnya. Hal ini disebabkan oleh keandalan SPIP masih berbeda dari masing-masing SKPD serta efektivitas pengendalian belum dievaluasi sehingga banyak terjadi kelemahan yang belum ditangani secara memadai. Tujuan penelitian ini adalah: (1) mengetahui bagaimana peran Inspektorat dalam pelaksanaan SPIP di Kabupaten Kepulauan Talaud; (2) menganalisis kendala-kendala yang mempengaruhi peran Inspektorat dalam pelaksanaan SPIP di Kabupaten Kepulauan Talaud; (3) menganalisis upaya-upaya yang dilakukan Inspektorat untuk meningkatkan pelaksanaan SPIP di Kabupaten Kepulauan Talaud. 


\section{Metode Penelitian}

Penelitian ini menggunakan metode kualitatif dengan pendekatan eksploratori (exploratory approach). Satori dan Komariah (2013:22) menjelaskan penelitian kualitatif adalah penelitian yang menekankan pada quality atau hal yang terpenting dari sifat suatu barang/jasa. Teknik pengumpulan data yang digunakan dalam penelitian ini adalah melalui wawancara, Observasi, dan Dokumentasi. Penelitian ini lebih difokuskan terhadap peran Inspektorat pada pemerintah daerah kabupaten secara menyeluruh, karena Inspektorat merupakan leader SPIP di kabupaten serta memiliki andil yang sangat besar dalam pelaksanaan Sistem Pengendalian Intern Pemerintah yang efektif. Metode analisis data yang digunakan peneliti yaitu Content Analysis (analisis isi).

\section{Analisis dan Pembahasan}

Analisis dilakukan berdasarkan data hasil penelitian yang diperoleh melalui wawancara mendalam terhadap 12 (dua belas) informan terpilih.

\section{Sistem Pengendalian Intern Pemerintah (SPIP)}

Sistem pengendalian internal merupakan suatu hal yang wajib dilaksanakan pada setiap organisasi pemerintahan. Untuk pelaksanaan Sistem Pengendalian Intern Pemerintah pada dasarnya sudah dilaksanakan secara alamiah dan masih sementara berproses untuk lebih baik, walaupun belum ada pedoman baku yang mengatur dan mengontrol terselenggaranya Sistem pengendalian Intern.

\section{Pelaksanaan Sistem Pengendalian Intern Pemerintah di Kabupaten Kepulauan Talaud}

\section{Lingkungan Pengendalian}

Dalam penerapan SPIP juga Pimpinan Instansi Pemerintah diwajibkan untuk bisa menciptakan lingkungan pengendalian yang kondusif, membangun hubungan antara pimpinan dan bawahan, membangun kekompakan.

\section{Penilaian Risiko}

Risiko merupakan penghambat dalam pencapaian tujuan suatu organisasi sehingga Instansi Pemerintah wajib melakukan penilaian risiko. Di Kabupaten Kepulauan Talaud sendiri sudah berjalan namun tidak semua SKPD sudah bisa melakukan penilaian risiko, secara umum Pemda sudah menerapkannya sehingga sudah mampu melakukan pengidentifikasian.

\section{Kegiatan Pengendalian}

Kegiatan pengendalian mencakup semua kegiatan yang dilakukan dalam pengawasan. Kegiatan pengendalian telah dilaksanakan melalui reviu laporan keuangan, reviu RPJM, reviu RKA, reviu kinerja, evaluasi, kegiatan pendampingan, pembinaan SDM dan lain-lain.

\section{Informasi dan Komunikasi}

Informasi dan komunikasi sudah berjalan dengan baik. Misalnya koordinasi dan konsultasi antara pimpinan dan bawahan, informasi yang datang cepat disampaikan kepada pimpinan namun tetap memisahkan informasi negatif yang tidak layak untuk dicerna. Informasi yang ada juga sudah relevan dan komunikasi sudah efektif.

\section{Pemantauan Pengendalian Intern}

Pemerintah daerah telah memiliki kebijakan prosedur pemantauan berkelanjutan antara lain supervisi kegiatan, pembandingan, rekonsiliasi, sidak dan prosedur lain semua ini telah dilaksanakan dengan baik.

\section{Manfaat Sistem Pengendalian Intern Pemerintah}

Menyadari betapa pentingnya SPIP ini maka Pemerintah sudah harus membentuk Satgas SPIP guna mendukung penyelenggaraanya di Pemerintahan. Korah (2016) dalam hasil penelitiannya menyatakan bahwa Peraturan Pemerintah Nomor 60 tahun 2008 jika dilakukan dengan efektif akan sangat membantu untuk meminimalisir risiko terjadinya kesalahan. Perlu kerjasama yang baik dalam menerapkan peraturan tersebut antara Pemda, Inspektorat sebagai pengendali intern maupun SKPD sebagai objek pemeriksaan. Menurut PwC (2011) Pengendalian internal adalah sebuah proses, yang dilakukan oleh dewan direksi, manajemen, dan personil perusahaan, yang dirancang untuk memberikan keyakinan memadai mengenai pencapaian tujuan dalam kategori: efektivitas dan efisiensi operasi, keandalan pelaporan dan kepatuhan terhadap hukum dan peraturan yang berlaku. Dengan demikian dapat dipahami bahwa sistem pengendalian yang didesain selain untuk mengatur semua komponen yang ada didalam perusahaan juga bisa berjalan dengan efektif dan efisien. 


\section{Penilaian Maturitas SPIP}

Dalam pelaksanaan SPIP Perwakilan BPKP Provinsi Sulawesi Utara melakukan penilaian Maturitas di Kabupaten Kepulauan Talaud dengan hasil penilaian sebesar "2,417" yang artinya berada pada level 2 atau berkembang. Adapun dalam rangka peningkatan untuk mencapai level 3 Maturitas SPIP seperti yang di targetkan oleh bapak Presiden Joko Widodo untuk tahun 2019, maka Inspektorat Kabupaten Kepulauan Talaud melakukan upaya-upaya seperti berkomitmen, memberikan keyakinan yang memadai, peringatan dini, memelihara atau meningkatkan kualitas tatakelola penyelenggaraan tugas dari setiap instansi atau setiap organisasi, mengikuti diklat atau pelatihan, penataan administrasi untuk meningkatkan kualitas pemeriksaan dan laporan keuangan, menambah jumlah auditor, melakukan konsultasi, koordinasi dengan BPKP serta perencanaan yang matang. Penilaian maturitas sangat penting untuk peningkatan efektivitas pengendalian intern dalam rangka pencapaian tujuan organisasi melalui kegiatan yang efektif dan efisien, keandalan laporan keuangan, pengamanan aset Negara dan ketaatan terhadap peraturan perundang-undangan (Perka No. 4 tahun 2016).

\section{Peran Inspektorat Dalam Pelaksanaan Sistem Pengendalian Intern Pemerintah di Kabupaten Kepulauan Talaud Kepemimpinan}

Untuk menjalankan amanatnya sebagai pembina pelaksana Sistem Pengendalian Intern Pemerintah di Kabupaten, Inspektorat melakukan perannya sebagai leader yang merupakan corong terdepan dengan cara melakukan koordinasi, melakukan fungsi kontrol, mendorong terciptanya reformasi birokrasi dan tata kelola pemerintahan yang baik, memberi saran terhadap kinerja dan manejemen risiko, sebagai penopang, sebagai wasit yang menilai tatanan pelaksanaan SPIP di tingkat SKPD dimana ketika dalam pelaksanaan terdapat kendala atau permasalahan, Inspektorat dapat memberikan solusi berupa rekomendasi untuk perbaikan kedepan. Fahmi (2013) menyatakan bahwa kepemimpinan adalah tentang bagaimana mengarahkan, mempengaruhi, dan mengawasi orang lain untuk mengerjakan tugas sesuai dengan perintah yang direncanakan.

\section{Pengawasan Intern}

Inspektorat diharapkan mampu melaksanakan perannya tersebut dalam mendorong terciptanya pemerintahan yang bersih dan untuk perbaikan atas penyelenggaraan pemerintahan melalui pelaksanaan SPIP. Mulyadi (2002) mengatakan bahwa pengendalian intern adalah Sistem pengendalian intern meliputi struktur organisasi, metode dan ukuran-ukuran yang dikoordinasikan untuk menjaga kekayaan organisasi, mengecek ketelitian dan keandalan data akuntansi, mendorong efisiensi dan mendorong dipatuhinya kebijaksanaan manajemen. Pengawasan internal yang baik merupakan alat yang dapat membantu Pemda dalam melaksanakan tugas dan fungsinya. Melalui pengawasan internal yang efektif, pemerintah juga dapat menilai apakah kebijakan dan prosedur yang ditetapkan telah dilaksanakan dengan baik sehingga tujuan daerah dapat tercapai. Aparat Pengawasan Intern Pemerintah dalam hal ini Inspektorat Kabupaten/Kota mempunyai fungsi Pengawasan Intern yang mencakup kegiatan yang berkaitan langsung dengan penjamin kualitas yang mendukung terselenggaranya pemerintahan yang efektif, transparan, akuntabel serta bersih dari praktek KKN.

\section{Konsultan (Consultant)}

Perubahan paradigma peran APIP dari watch dog menjadi konsultan diharapkan mampu memberikan pembinaan, pembimbingan, saran terkait aktivitas organisasi dan lingkup penugasan dapat disepakati bersama untuk memberikan nilai tambah dan perbaikan risiko, pengendalian, dan proses tata kelola organisasi. Dalam menjalankan peran sebagai konsultan, Inspektorat Kabupaten Kepulauan Talaud membuka ruang yang selebar-lebarnya kepada semua SKPD yang ingin melakukan konsultasi terkait dengan masalah-masalah dalam pengelolaan keuangan daerah, baik di tingkat SKPD sampai tingkat desa, khususnya lagi konsultasi pertanggungjawaban dana desa. Pelaksanaan peran sebagai konsultan Inspektorat untuk terus meningkatkan kompetensi dan pengetahuannya, karena sebagai konsultan Inspektorat harus lebih banyak tahu dari pada pihak yang melakukan konsultasi terkait pengelolaan keuangan daerah yang sesuai dengan peraturan perundang-undangan yang ada.

\section{Penjamin Mutu (Quality Assurance)}

Seiringan dengan perubahan peran menjadi konsultan, Inspektorat juga mengalami pergeseran menjadi penjamin mutu, sebagai agen perubahan yang memberikan penilaian independen tentang manajemen risiko, pengendalian dan proses tata kelola sebagai contoh dapat melaksanakan tugas audit terkait keuangan, kinerja, ketaatan, dan keamanan sistem. Inspektorat Daerah sebagai Aparat 
Pengawasan Internal Pemerintah berperan sebagai Quality Assurance yaitu menjamin bahwa suatu kegiatan dapat berjalan secara efisien, efektif dan sesuai dengan aturannya dalam mencapai tujuan organisasi. Quality Assurance dalam setiap pelaksanaan audit, diharapkan mampu mengidentifikasi risiko dan mendorong proses perbaikan yang berkelanjutan, mendorong APIP Inspektorat Kabupaten Kepulauan Talaud untuk melaksanakan salah satu perannya sebagai penjamin mutu.

\section{Kendala-kendala Yang Mempengaruhi Peran Inspektorat Dalam Pelaksanaan SPIP Di Kabupaten Kepulauan Talaud Dasar Hukum}

Dalam PP Nomor 60 tahun 2008 tentang Sistem Pengendalian Intern Pemrintah, dijelaskan bagaimana pelaksanaan SPIP serta peran dan fungsi Inspektorat dalam mewujudkan pemerintahan yang efektif. Pemerintah Kabupaten Kepulauan Talaud sampai saat ini belum didukung oleh peraturan daerah sebagai penjabaran dari PP No. 60 tahun 2008. Salah satu kendala yang ditemukan dalam penelitian ini adalah Dasar Hukum yang diuraikan dalam 3 (tiga) aspek yakni : belum ada aturan Kepala Daerah (Perbup), pedoman yang baku atau surat keputusan untuk mengatur penyelenggaraan SPIP, belum membentuk Satuan Tugas SPIP dan SPIP sudah dipahami tapi belum menjadi prioritas dan belum dilakukan secara terus menerus. Menurut Tyler (dalam Septiani, 2005) terdapat dua perspektif dasar dalam literatur sosiologi mengenai kepatuhan pada hukum, yang disebut instrumental dan normatif. Perspektif instrumental mengasumsikan individu secara utuh didorong oleh kepentingan pribadi dan tanggapan terhadap perubahan-perubahan dalam tangible, insentif, dan penalti yang berhubungan dengan perilaku. Perspektif normatif berhubungan dengan apa yang orang anggap sebagai moral dan berlawanan dengan kepentingan pribadi mereka.

Hal ini disebabkan belum adanya peraturan daerah melalui peraturan Bupati tentang Sistem Pengendalian Intern Pemerintah yang baku sehingga SPIP belum mendapat perhatian penuh dari pemerintah itu sendiri. Inspektorat diharapkan untuk bisa menjembatani dalam pembentukan peraturan tentang SPIP, dengan adanya peraturan tersebut Inspektorat lebih memiliki power dalam melaksanakan tugasnya sebagai pengendali dengan maksimal karena didukung dengan peraturan dan dilindungi secara hukum. Pada PP No. 60 tahun 2008 pasal 60 dijelaskan bahwa ketentuan mengenai SPIP di lingkungan pemerintah daerah diatur lebih lanjut dengan peraturan Gubernur atau peraturan Bupati/Walikota dengan berpedoman pada peraturan ini, dengan demikian sudah seharusnya Pemda membuat peraturan Bupati tentang Sistem Pengendalian Intern Pemerintah yang baku. Inspektorat diharapkan untuk bisa menjembatani dalam pembentukkan peraturan tentang SPIP, dengan adanya peraturan tersebut Inspektorat lebih memiliki power dalam melaksanakan tugasnya sebagai pengendali dengan maksimal karena didukung dengan peraturan dan dilindungi secara hukum.

\section{Kualitas SDM}

Tiga hal yang sangat berpengaruh sehingga kualitas SDM menjadi salah satu kendala dalam pelaksanaan SPIP. Yang pertama adalah kualitas SDM yang belum mampu baik dalam tingkat pemahaman akan SPIP maupun dalam hal penempatan sesuai kebutuhan, serta pelatihan, diklat, bintek untuk pengembangan kapasitas yang masih kurang, sehingga mengakibatkan minimnya pengetahuan mengenai SPIP. Jumlah personil di Inspektorat yang belum memenuhi sehingga tidak seimbang dengan jumlah objek pemeriksaan serta pergantian pimpinan yang kemudian menyebabkan SPIP luput dari perhatian. Sikula (2001) menyatakan bahwa pengembangan SDM mengacu pada kepentingan staf dan personil yang ada di dalam organisasi. Pengembangan SDM merupakan proses pembelajaran jangka panjang dengan menggunakan prosedur yang sistematis dan terorganisasi, dimana manajer mempelajari pengetahuan konseptual dan teoritis, yang kemudian diimplementasikan dalam pengembangan SDM. Pengembangan SDM juga merupakan aktivitas memelihara dan meningkatkan kompetensi SDM guna mencapai efektivitas organisasi.

\section{Anggaran Kegiatan Pengawasan}

Dalam suatu pemerintahan tentunya sangat membutuhkan anggaran, terlebih khusus pada pelaksanaan tugas pengawasan daerah yang secara lembaga dilakukan oleh Inspektorat. Mulyadi (2002) menyebutkan bahwa anggaran berdasarkan fungsinya adalah untuk mencapai tujuan organisasi. Anggaran dibutuhkan dalam rangka mendukung pelaksanaan tugas yang maksimal. Namun hal ini belum terealisasi sehingga mengakibatkan kegiatan pengawasan di Kabupaten tidak bisa terlaksana secara menyeluruh. Dalam hal ini pemerintah perlu memberi perhatian lebih dengan meningkatkan anggaran untuk kegiatan pengawasan sehingga keseluruhan tugas pengawasan khususnya SPIP dapat dilaksanakan dengan maksimal demi mencapai tujuan pemerintah. 


\section{Komitmen}

Untuk mencapai tujuan setiap organisasi membutuhkan komitmen. Demikian juga dengan Kabupaten Kepulauan Talaud dalam upaya penyelenggaraan SPIP menurut PP No. 60 tahun 2008, maka pemerintah baik Kepala Daerah maupun pimpinan SKPD harus berkomitmen agar hal tersebut bisa dilaksanakan demi tercapainya tujuan daerah. Menurut Teori Peran (Role Theory) bahwa peranan (role) merupakan proses dinamis kedudukan (status). Apabila seseorang melaksanakan hak dan kewajibannya sesuai dengan kedudukannya, dia menjalankan suatu peranan (Soekanto, 2002). Inspektorat merupakan suatu lembaga pengawasan di lingkungan pemerintah daerah, memainkan peranan yang sangat penting dan signifikan untuk kemajuan dan keberhasilan pemerintah dalam menyelenggarakan pemerintahan dan mencapai tujuan yang telah ditetapkan. Peran dan fungsi Inspektorat antara lain sebagai mitra kerja pemerintah daerah untuk memudahkan setiap Satuan Kerja Perangkat Daerah (SKPD) di unit kerja masing-masing agar dapat mencapai tujuan dan sasaran kegiatan operasionalnya dengan efektif dan efisien.

\section{Pengawasan Berbasis Risiko}

Inspektorat telah melakukan penilaian risiko maupun pemetaan risiko namun belum optimal, keterbatasan waktu juga menyebabkan hal ini tidak dilakukan dengan maksimal. Hal ini berdampak pada SKPD sehingga mereka juga belum bisa melakukan penilaian risiko dan pemetaan risiko secara optimal karena sebagian besar belum tahu bagaimana melakukan penilaian risiko. Pengawasan berbasis risiko merupakan hal penting dalam rangka memenuhi peran Inpektorat untuk memberikan keyakinan yang memadai, peringatan dini serta memelihara dan meningkatkan kualitas tata kelola penyelenggaraan pemerintahan. Inspektorat diharapkan senantiasa melakukan pendampingan dalam penilaian risiko pada setiap SKPD, mampu melakukan pemetaan risiko, mengidentifikasi risiko yang ada, hal ini sudah mulai dilakukan setiap awal tahun namun belum optimal.

\section{Upaya-upaya Yang Dilakukan Inspektorat Untuk Meningkatkan Pelaksanaan SPIP di Kabupaten Kepulauan Talaud \\ Dasar Hukum}

Upaya menjawab permasalahan yang diuraikan sebelumnya maka Inspektorat mulai bergerak cepat untuk segera mengusulkan penyusunan Peraturan Bupati baik berupa pedoman, Surat Keputusan maupun pengusulan pembentukan Satuan Tugas SPIP. Dari berbagai pernyataan yang dijelaskan sebelumnya, maka Inspektorat diharapkan dapat segera menindak lanjuti untuk segera mengusulkan penyusunan Perbup baik berupa pedoman, Surat Keputusan maupun pengusulan pembentukan Satuan Tugas SPIP. Diharapkan juga Inspektorat dapat memberikan pemahaman akan pentingnya pelaksanaan SPIP baik melalui sosialisasi, asistensi maupun konsultasi. Seperti yang dijelaskan sebelumnya bahwa saat ini Inpektorat membuka ruang untuk semua pihak yang berkepentingan dalam menyelesaikan persoalan pengelolaan keuangan, hal ini merupakan suatu kemajuan yang sangat baik dalam upaya terselenggaranya pemerintahan yang baik.

\section{Kualitas Sumber Daya manuasia (SDM)}

Upaya yang dilakukan Inspektorat diantaranya mengusulkan bahwa pengembangan kualitas sumber daya harus ditingkatkan, melalui jenjang pendidikan, diklat-diklat, bintek ataupun pelatihan kantor sendiri, pembinaan, melakukan koordinasi meningkatkan pendidikan dengan lembaga-lembaga seperti BPKP. Sikula (2001) mengatakan pengembangan SDM mengacu pada kepentingan staf dan personil yang ada di dalam organisasi. Pengembangan SDM merupakan proses pembelajaran jangka panjang dengan menggunakan prosedur yang sistematis dan terorganisasi, dimana manajer mempelajari pengetahuan konseptual dan teoritis, yang kemudian diimplementasikan dalam pengembangan SDM. Pengembangan SDM juga merupakan aktivitas memelihara dan meningkatkan kompetensi SDM guna mencapai efektivitas organisasi.

\section{Anggaran Kegiatan Pengawasan}

Untuk meningkatkan peran sebagai pembina di kabupaten dalam pelaksanaan Sistem Pengendalian Intern Pemerintah Kabupaten, Inspektorat melakukan berbagai upaya agar seluruh kegiatan pengawasan dapat dilaksanakan dengan maksimal maka perlu penambahan anggaran. Upaya dilakukan dengan cara mengusulkan penambahan anggaran agar kegiatan pengawasan dapat dilaksanakan secara menyeluruh dan optimal. Sangat diharapkan perhatian yang besar dari pemerintah atas usulan yang telah disampaikan. Mulyadi (2002) menyebutkan bahwa anggaran berdasarkan 
fungsinya adalah untuk mencapai tujuan organisasi. Anggaran dibutuhkan dalam rangka mendukung pelaksanaan tugas yang maksimal.

\section{Komitmen}

Komitmen dari ibu Bupati bahwa penyelenggaraan pemerintahan semakin transparan dan akuntabel itu harus kuat. Keberhasilan suatu organasasi untuk mencapai tujuan selalu membutuhkan komitmen. Dalam Modul Manajemen Fungsi Audit Internal Sektor Publik (2007) menyebutkan komitmen untuk memperkuat posisi atau kedudukan dari fungsi pengawasan di lingkungan pemerintah daerah, kepala Inspektorat harus membuat "Audit charter", yaitu dokumen tertulis formal yang merumuskan tujuan, wewenang dan tanggung jawab Inspektorat dalam menjalankan fungsi pengawasan. Audit charter Inspektorat adalah anggaran dasar dari unit kerja Inspektorat sebagai fungsi pengawasan yang menggambarkan tujuan, wewenang, dan tanggung jawab dari Inspektorat yang melaksanakan dan berperan sebagai fungsi pengawasan internal di lingkungan Pemda. Komitmen pemerintah daerah sangat penting agar Inspektorat dapat memaksimalkan pelaksanaan SPIP, terutama untuk bisa membentuk peraturan/pedoman serta Satgas SPIP.

\section{Pengawasan Berbasis Risiko}

Inspektorat melakukan berbagai upaya untuk segera mengatasi permasalahan tersebut. Kalau dulunya Inspektorat melakukan pengendalian dengan pengawasan berbasis risiko melalui kegiatan PKPT (Program Kerja Pemeriksaan Tahunan) yang bersifat reguler dan berlandaskan analisis risiko, untuk tahun 2017 ini akan ditingkatkan lagi menjadi lebih spesifik yaitu PDT2 (Pemeriksaan Dengan Tujuan Tertentu). Dengan demikian setiap SKPD harus melakukan pengendalian sejak awal melalui penilaian risiko dengan cara mengidentifikasi risiko, menganalisis risiko, melakukan kegiatan pemetaan risiko sehingga untuk setiap program/kegiatan sudah diketahui mana yang memiliki risiko dan harus diwaspadai serta perlu ditangani dengan cepat dan tepat.

\section{Komunikasi Yang Efektif}

Komunikasi merupakan hal yang penting dalam suatu organisasi. Membangun komunikasi yang baik dan melakukannya secara intens dengan SKPD maupun BPKP selaku Pembina SPIP Kabupaten/Kota merupakan salah satu upaya untuk melaksanakan pembinaan SPIP. Mulai dari melakukan pelatihan kantor sendiri untuk menyamakan persepsi seluruh SKPD, saling berkoordinasi, melakukan evaluasi berkala melalui rapat-rapat, menjadi konsultan dan memberi pemahaman dalam penyelesaian permasalahan SKPD, memberikan informasi melalui sosialisasi tentang SPIP di setiap kegiatan pengawasan.

\section{Keterbatasan Penelitian}

Keterbatasan penelitian ini adalah adanya informan yang memiliki masa jabatan 6 bulan karena adanya pembentukan OPD baru, sehingga terdapat pelantikan dengan nomenklatur jabatan dan Badan/Dinas yang baru serta terbatasnya waktu atau kesempatan karena libur hari raya Idul Fitri, kesibukan pekerjaan informan dan kesibukan dalam persiapan HUT Kabupaten Kepulauan Talaud. Penelitian ini juga dibatasi pada 2 (dua) orang Korwas BPKP Perwakilan Sulut dengan pertanyaan yang tidak lebih sedikit dari 10 informan lainnya karena bersifat umum, 7 (tujuah) orang PNS di Inspektorat Kabupaten Kepulauan Talaud yang terkait dengan penelitian dan 3 orang pejabat masingmasing dari Badan Pengelola Pajak dan Retribusi Daerah, Dinas Pekerjaan Umum dan Tata Ruang, Dinas Kependudukan dan Pencatatan Sipil Kabupaten Kepulauan Talaud yang memahami PP No. 60 tahun 2008 tentang Sistem Pengendalian Intern Pemerintah.

\section{Penutup}

Kesimpulan penelitian ini adalah (1) Peran Inspektorat dalam pelaksanaan SPIP di Kabupaten Kepulauan Talaud yaitu dalam hal kepemimpinan, pengawasan intern, konsultan dan penjamin mutu. (2) Kendala-kendala yang mempengaruhi peran Inspektorat dalam pelaksanaan SPIP di Kabupaten Kepulauan Talaud yaitu belum adanya Peraturan Bupati dan belum membentuk Satuan Tugas SPIP, pemahaman SDM akan SPIP masih kurang dan jumlah personil belum memadai, anggaran kegiatan pengawasan kurang memadai, belum ada komitmen bersama dalam melaksanakan SPIP serta penilaian risiko dan pemetaan risiko belum optimal karena keterbatasan waktu (3) Upaya-upaya yang dilakukan Inspektorat untuk meningkatkan pelaksanaan SPIP di Kabupaten Kepulauan Talaud adalah dengan mengusulkan penyusunan Peraturan Bupati dan pembentukan Satuan Tugas SPIP, meningkatkan kualitas sumber daya, melalui jenjang pendidikan, diklat-diklat, bintek ataupun 
pelatihan kantor sendiri, pembinaan, melakukan koordinasi meningkatkan pendidikan dengan lembaga-lembaga seperti BPKP, menambah anggaran kegiatan pengawasan, membangun komitmen bersama dalam melaksanakan SPIP, melakukan penilaian risiko dan pemetaan risiko secara optimal dan membangun komunikasi yang efektif dengan SKPD maupun BPKP.

Saran yang dapat diberikan dari penelitian ini yaitu (1) Bagi Pemerintah daerah: Penyusunan Perbup dan pembentukan Satgas SPIP mengacu pada ketentuan yang berlaku. Penambahan anggaran agar kegiatan pengawasan dapat dilaksanakan secara menyeluruh dan optimal. Membangun komitmen bersama untuk melaksanakan SPIP (2) Bagi Inspektorat: Mengembangkan kualitas sumber daya melalui jenjang pendidikan, diklat-diklat, bintek ataupun pelatihan kantor sendiri, pembinaan untuk peningkatan kinerja Inspektorat sebagai Aparat Pengawasan Intern Pemerintah dalam melaksanakan SPIP, melakukan penilaian risiko secara optimal dan membangun komunikasi yang efektif dengan SKPD maupun BPKP. (3) Bagi Akademisi: Penelitian ini dapat memperkaya khasanah perkembangan ilmu pengetahuan di dunia pendidikan/akademis, khususnya terkait dengan pelaksanaan SPIP dan dapat menjadi bahan referensi terhadap penelitian selanjutnya.

\section{Daftar Pustaka}

Arikunto, Suharsimi. 2010. Prosedur Penelitian : Suatu Pendekatan Praktik. Jakarta: Rineka Cipta.

Armando, Gerry. 2012. Pengaruh Sistem Pengendalian Intern Pemerintah dan Pengawasan Keuangan Daerah Terhadap Nilai Informasi Laporan Keuangan Pemerintah. Jurnal. Universitas Negeri Padang. Sumatera Utara.

Astuti, Sri. 2014. Analisis Implementasi Pp No. 60 tahun 2008 tentang Sistem Pengendalian Internal Terhadap Penatausahaan Keuangan Daerah Pada Kantor Camat Tebas. Jurnal. Vol. 3, No 4, 2014. Tebas : Sambas.

Badara, Mu'azusaidu and Siti Zabedah Saidin. 2012. The status of Internal Audit at Local Government Level in Nigeria. Journal of Business and Management (IOSR-JBM) ISSN:2278-487X. Volume 5, Issue 5 (November-December) 2012.

2013. Impack of Effective Internal Control System Of The Internal Audit Effectiveness at Local Government Level. Journal of Social and Development Sciences. Vol. 4, No. 1, pp. 16-23, Jan 2013. Universiti Utara Malaysia.

Bastian. I. dan Soepriyanto. G. 2002. Sistem Akuntansi Sektor Publik. Buku 1. Jakarta: Salemba Empat.

Bastian. I. 2007. Sistem Akuntansi Sektor Publik. Jakarta : Salemba Empat.

Bungin, Burhan. 2015. Penelitian Kualitatif. Jakarta : Prenada Media Group. 2015. Metodologi Penelitian Kualitatif. Jakarta : PT. Raja Grafindo Persada.

Creswell, John W. 2012. Educational Research : Planning, Conducting, And Evaluating Quantitative and Qualitative Research. 4th Edition. Pearson. University of Nebraska-Lincoln.

Fahmi, Irham. 2013. Manajemen Pengambilan Keputusan. Bandung : Alfabeta. 2014. Perilaku Organisasi. Bandung : Alfabeta.

Freeman, R. E. 1984. Strategic Management: A Stakeholder Approach. Boston: Pitman.

Gerry, Armando. 2012. Pengaruh Sistem Pengendalian Intern Pemerintah dan Pengawasan Keuangan Daerah Terhadap Nilai Informasi Laporan Keuangan Pemerintah. Artikel. Universitas Negeri Padang. Sumatera Utara.

Gibson, Vancevich, Donnelly. 1996. Organisasi, Perilaku, Struktur, Proses. Jakarta : Bina Rupa Aksara.

Hasibuan, Malayu. 2003. Manajemen Sumber Daya Manusia: Pengertian Dasar, Pengertian, dan Masalah. Jakarta : Bumi Aksara.

Hidayat, Kemal dan Rustan A. 2015. Analisis Penerapan Unsur Lingkungan Pengendalian SPIP di Lingkungan Pemerintah Kabupaten Kutai Kartanegara. Jurnal Borneo Administrator. Volume 11, Nomor 1. 2015. Kutai Kartanegara. Samarinda.

Hindriani Nuning, Imam Hanafi, Tjahjanulin Domai. 2012. Sistem Pngendalian Intern Pemerintah (SPIP) dalam Perencanaan dan Pelaksanaan Anggaran di Daerah. Jurnal Wacana. Volume 15, Nomor 3. 2012. Universitas Brawijaya. Mediun.

Horton, Paul B. dan Chester L. Hunt. 1993. Sosiologi. Terjemahan Aminuddin Ram dan Tita Sobari. Jakarta : Erlangga.

Indriasih, Dewi. 2014.The Effect Of Government Apparatus Competence And The Effectiveness Of Government Internal Control Toward The Quality Of Financial Reporting And its Impact On The 
Performance Accountability In Local Government. South East Asia Journal of Contemporary Business, Economics and Law. Vol. 5, Issue 1 (Dec.) 2014. Tegal City : Central Java Province.

Ismani, Andian Ari Istiningrum, Mahendra Adhi Nugroho, \& Adeng Pustikaningsih. 2014. Implementasi Sistem Pengendalian Intern Pemerintah di Universitas Negeri Yogyakarta. Jurnal Economia. Volume 10, Nomor 1, April 2014. Yokyakarta.

Jensen, M. C. dan Meckling, W. H. (1976). Theory of the firm: Managerial behavior, agency costs and ownership structure. Journal of Financial Economics, 3, 305-360.

Kabupaten Kepulauan Talaud. Peraturan Daerah Nomor 06 Tahun 2008 tentang Organisasi dan Tata Kerja Inspektorat, Lembaga Teknis Daerah, Satuan Polisi Pamong Praja Kabupaten Kepulauan Talaud. Melonguane.

. Peraturan Bupati Nomor 31 Tahun 2008 tentang Uraian Tugas Pokok dan Fungsi Inspektorat Kabupaten Kepulauan Talaud. Melonguane.

Komaruddin. 1994. Ensiklopedia Manajemen. Jakarta : Bumi aksara.

Korah, Theyza. 2016. Analisis Penerapan Peraturan Pemerintah Nomor 60 Tahun 2008 Tentang Sistem Pengendalian Intern Pemerintah Pada Inspektorat Di Provinsi Sulawesi Utara.Tesis. Universitas Sam Ratulangi. Manado.

Lalic S, D. Jovanovic, M. Nikolic, V. Vulovic. 2011. Internal Control and Problems of Modern Management In The International Environment. Research Journal of Agricultural Science, 43 (3), 2011.

Lambey, Linda. 2015. Mental Models Of Employment And The Psychological Contracts Of Indonesian Academics: An Exploratory Study. Thesis : The University of Newcastle. Australia.

Luthans, Fred. 2011. Organizational Behavior. McGraw-Hill. New York.

Lunenburg. 2012. Compliance Theory and Organizational Efektiveness. International Journal Of Scholarly Academic Intellectual DiversityVol. 14, No. 1.

Mihaela, Dumitrascu dan Savulescu Iulian. 2012. Internal Control and the Impact on Corporate Governance, in Romanian Listed Companies. Journal of Eastern Europe Research in Business \& Economics. 1-10. Vol. 2012. Academy of Economic Studies, Bucharest, Romania.

Mulyadi. 2001. Auditing. Edisi 6. Jakart : Salemba Empat. 2002. Auditing Edisi 6. Jilid 1. Jakarta : Salemba Empat.

Mulyani Pujianik, Rindah F. Suryawati. 2011. Analisis Peran dan Fungsi Sistem Pengendalian intern Pemerintah (SPIP/PP No.60 Tahun 2008) Dalam Meminimalisasi Tingkat Salah Saji Pencatatan Akuntansi Keuangan Pemerintah Daerah. Jurnal Organisasi dan Manajemen, Volume 7, Nomor 2, September 2011, 102-116. Universitas Trunojoyo Madura.

Musfiqon. 2012. Panduan Lengkap Metodologi Penelitian Pendidikan. Jakarta: PT. Prestasi Pustakaraya.

Priansa, Donni Juni. 2016. Perencanaan Dan Pengembangan SDM. Bandung : Alfabeta.

PricewaterhouseCoopers. 2011. Internal Control-Integrated Framework. New York: Committee of Sponsoring Organizations of the Treadway Commission.

Rahmat, Sentot. 2010. Analisis peran Inspektorat Jenderal sebagai Aparat Pengawasan Internal Kementerian/Lembaga dalam meningkatkan kualitas laporan Keuangan Kementerian/Lembaga. Tesis. Fakultas Ekonomi Universitas Indonesia. Jakarta.

Republik Indonesia. Peraturan Pemerintah Nomor 8 Tahun 2006 tentang Pelaporan Keuangan dan Kinerja Instansi Pemerintah. Jakarta.

. Peraturan Pemerintah Nomor 60 Tahun 2008, tentang Sistem Pengendalian Intern Pemerintah. Jakarta.

Peraturan Menteri Negara Pendayagunaan Aparatur Negara Nomor PER/05/M.PAN/2008 Tahun 2008 tentang Standar Audit Aparat Pengawasan Intern Pemerintah. Jakarta.

. Peraturan Menteri Dalam Negeri Nomor 13 Tahun 2006 tentang Pedoman Pengelolaan Keuangan Daerah. Jakarta.

Peraturan Menteri Dalam Negeri Nomor 64 Tahun 2007 tentang Pedoman Teknis Organisasi dan Tata Kerja Inspektorat Provinsi dan Kabupaten/Kota. Jakarta.

Peraturan Menteri Negara Pendayagunaan Aparatur Negara Nomor : Per/05/M.Pan/03/2008 tentang Standar Audit Aparat Pengawasan Intern Pemerintah Menteri Negara Pendayagunaan Aparatur Negara. Jakarta.

Robbins, Stephen P dan Timoty A Judge. 2015. Perilaku Organisasi. Edisi 16. Jakarta Selatan : Salemba Empat. 
Sari, Maya. 2015. Peran Badan Pengawasan Keuangan dan Pembangunan Dalam Pelaksanaan Sistem Pengendalian Intern Pemerintah Pada Pemerintah Daerah Sumatera Utara. Seminar Nasional Ekonomi Manajemen Dan Akuntansi (SNEMA)-2015. ISBN: 978-602-17129-5-5, 569577. Universitas Negeri Padang. Sumatera Utara.

Sikula Sr, A. (2001). The five biggest HRM lies. Public Personnel Management, 30(3), 419-428.

Simangunsong, Rosma. 2014. The Impact of Internal Control Effectiveness and Internal Audit Role toward the Performance of Local Government. Research Journal of Finance and Accounting. Vol. 5, No. 7, 2014. Padjadjaran University. Indonesia.

Satori, Djam'an dan Aan Komariah. 2013. Metodologi Penelitian Kualitatif. Bandung: Alfabeta.

Sekolah Tinggi Akuntansi Negara. 2007. Modul Manajemen Fungsi Audit Internal SektorPublik. Tangerang: YPIA.

Sembiring, Tenun. 2009. Fungsi dan tugas Inspektorat dalam Pengendalian Internal Barang Milik Daerah pada pemerintah Kabupaten Karo Sumatra Utara. Skripsi. Fakultas Ekonomi Universitas. Medan.

Septiani, Aditya. 2005. Faktor-faktor Yang Mempengaruhi Ketepatan Waktu Pelaporan Keuangan Pada Pasar Modal Yang Sedang Berkembang: Perspektif Teori Pengungkapan.Tesis. Universitas Diponegoro. Semarang.

Shanmugam, Jaya Kumar and Mohd Hassan Che Haat Azwadi Ali. 2012. The Impact of Internal Control on the Performance of Small and Medium Enterprise: Malaysian Evidence. Conference Paper. SIBR Conference on Interdisciplinary Business and Economics Research, 7th-9th June 2012. Bangkok.

Soekanto, Soerjono. 2002. Teori Peranan. Jakarta: Bumi Aksara.

Sugiyono, 2005. Metode Penelitian Kualitatif. Bandung: Alfabeta.

2014. Metode Penelitian Kuantitatif, Kualitatif, dan Kombinasi (Mixed Methods).

Bandung: Alfabeta. 2010. Metode Penelitian Kuantitatif, Kualitatif, dan R\&D. Bandung: Alfabeta.

2016. Metode Penelitian Kuantitatif, Kualitatif dan R\&D. Bandung: Alfabeta.

Sujarweni, V. W. 2014. Metodologi Penelitian. Yogyakarta: Pustaka Baru Press. Vol.I.

Suwanda, Dadang dan Dailibas. 2016. Panduan Penerapan Sistem Pengendalian Intern Pemerintah. Jakarta Pusat: PPM.

Suwatno, H dan Priansa D. J. 2016. Manajemen SDM dalam Organisasi Publik dan Bisnis. Bandung: Alfabeta.

Trayambak, Shruti, Pranab Kumar, A. N Jha. 2012. A Conceptual Study on Role Stressors, their Impact and Strategies to Manage Role Stressors. IOSR Journal of Business and Management (IOSRJBM). 4 (1) PP:44-48.

Winardi. 1996. Istilah Ekonomi. Bandung: Mandar Maju.

Yohanes Elieser, Adri Paton, Anwar Alaydrus. 2016. Peran Aparat Pengawas Intern Pemerintah (APIP) Dalam Penyelenggaraan Pemerintahan Daerah Di Kabupaten Bulungan. eJournal Administrative Reform. Volume 4, Nomor 1. Hal. 65-78. 2016. 